\title{
A New Species of Cordia (Cordiaceae, Boraginales) from Brazil
}

\author{
María Natividad Sánchez de Stapf, ${ }^{1,2}$ Neusa Taroda Ranga, ${ }^{3}$ and \\ Tânia Regina dos Santos Silva ${ }^{1}$
}

${ }^{1}$ Departamento de Ciências Biológicas, Universidade Estadual de Feira de Santana, Km 03,

BR 116, Campus, 44031-460, Feira de Santana, Bahia, Brazil

${ }^{2}$ Smithsonian Tropical Research Institute, Apartado 0843-03092, Balboa, República de

Panamá.stapfm@si.edu

${ }^{3}$ Departamento de Zoologia e Botânica, Instituto de Biociências, Letras e Ciências Exatas, Universidade Estadual Paulista, 15054-020, São José do Rio Preto, São Paulo, Brazil

Abstract. A new species from Brazil, Cordia pilosa M. Stapf \& Taroda (Cordiaceae), is described from northeastern Brazil. Illustrations and data on habitat, distribution, and phenology are provided. The new species belongs to Cordia sect. Superbiflorae Taroda, and it is distinguished from similar species in section Superbiflorae by its compact inflorescences and the pilose indument on the twigs, leaves, and inflorescence axes.

Resumen. Se describe e ilustra una nueva especie para el noreste de Brasil: Cordia pilosa M. Stapf \& Taroda (Cordiaceae). También se presentan datos sobre su hábitat, distribución y fenología. Esta nueva especie pertenece a Cordia sect. Superbiflorae Taroda, y se distingue de las especies similares de la sección Superbiflorae por sus inflorescencias compactas y sus ramas jóvenes, hojas y ejes de las inflorescencias con indumento piloso.

Key words: Bahia, Brazil, Cordia, Cordiaceae, IUCN Red List.

Cordia L. is the largest genus of Cordiaceae, with about 250 species, and its distribution is pantropical (Miller, 2001; Miller \& Gottschling, 2007). In Brazil, approximately 45 species occur, most concentrated in evergreen lowland and seasonally dry tropical forest. During the study of the Brazilian species of Cordia, the taxonomic novelty $C$. pilosa M. Stapf \& Taroda was recorded from the states of Alagoas, Bahia, and Sergipe in northeastern Brazil.

Cordia pilosa belongs to Cordia sect. Superbiflorae Taroda, a natural group distributed mainly in northeastern and southeastern Brazil. This section is characterized by its whitish large corolla (more than $1.5 \mathrm{~cm}$ long) and its fruit that is halfway surrounded by the persistent calyx (Taroda \& Gibbs, 1986).

Cordia pilosa M. Stapf \& Taroda, sp. nov. TYPE: Brazil. Bahia: Entre Rios, rd. Conde-Esplanada, $11^{\circ} 46^{\prime} 17^{\prime \prime} \mathrm{S}, 37^{\circ} 44^{\prime} 05^{\prime \prime} \mathrm{W}, 23$ Jan. 2004, M. N. S. Stapf 228 (holotype, HUEFS; isotype, SJRP). Figure 1.

Haec species inter congeneros ad Cordiam sect. Superbifloras Taroda pertinentes quoad floribus grandibus Cordiae superbae Cham. et $C$. rufescenti A. DC. arcte affinis, sed a hac corolla majore, ab omnibus indumento piloso atque corollae lobis reflexis differt.

Shrub to $4.5 \mathrm{~m}$ tall; bark grayish, finely fissured; twigs densely pilose, trichomes ca. $2 \mathrm{~mm}$, brown. Leaves persistent, homomorphic; petioles 1.4-1.7 cm, pilose; blade oblanceolate to elliptic, 24.0-30.2 $\times$ 6.4-8.5 cm, apex acute to slightly acuminate, base cuneate, margin entire, adaxial surface glabrescent, with trichomes on the major veins, abaxial surface pilose; venation brochidodromous, midrib slightly prominent or even on adaxial surface, prominent on abaxial surface, secondary veins 11 to 13 , tertiary venation reticulate. Inflorescences terminal, cymose, condensed, 4.5-5.8 cm wide, branches as cincinnus, pilose, trichomes $2-3 \mathrm{~mm}$. Flowers bisexual, distylous; calyx tubular, 12.2-13.0 $\times$ ca. $6 \mathrm{~mm}$ (width at the mouth), striate, unevenly 2-lobed; corolla white, funnel-shaped, $3.8-4.0 \mathrm{~cm}$, lobes reflexed; stamens 5, filaments 13-16 mm, uneven, base pilose, trichomes ca. $1 \mathrm{~mm}$; ovary ovoid, ca. $3 \times 1.8 \mathrm{~mm}$, glabrous, style 18-20 mm (short-styled flowers) or 30-34 mm (long-styled flowers), stigmas filiform. Fruit drupaceous, white at maturity, glabrous, surrounded by the slightly accrescent, persistent, cupshaped calyx, ovoid, 13.5-14.2 × 7.8-8.2 mm, exocarp glabrous, mesocarp mucilaginous, stone erect, ellipsoid.

Distribution and habitat. Cordia pilosa is known only from Alagoas, Bahia, and Sergipe in Brazil, where it occurs in the Atlantic coastal forest, specifically in restinga vegetation (sandy plains along the coast), below $100 \mathrm{~m}$ in elevation. It is apparently endemic to northern Brazil. 


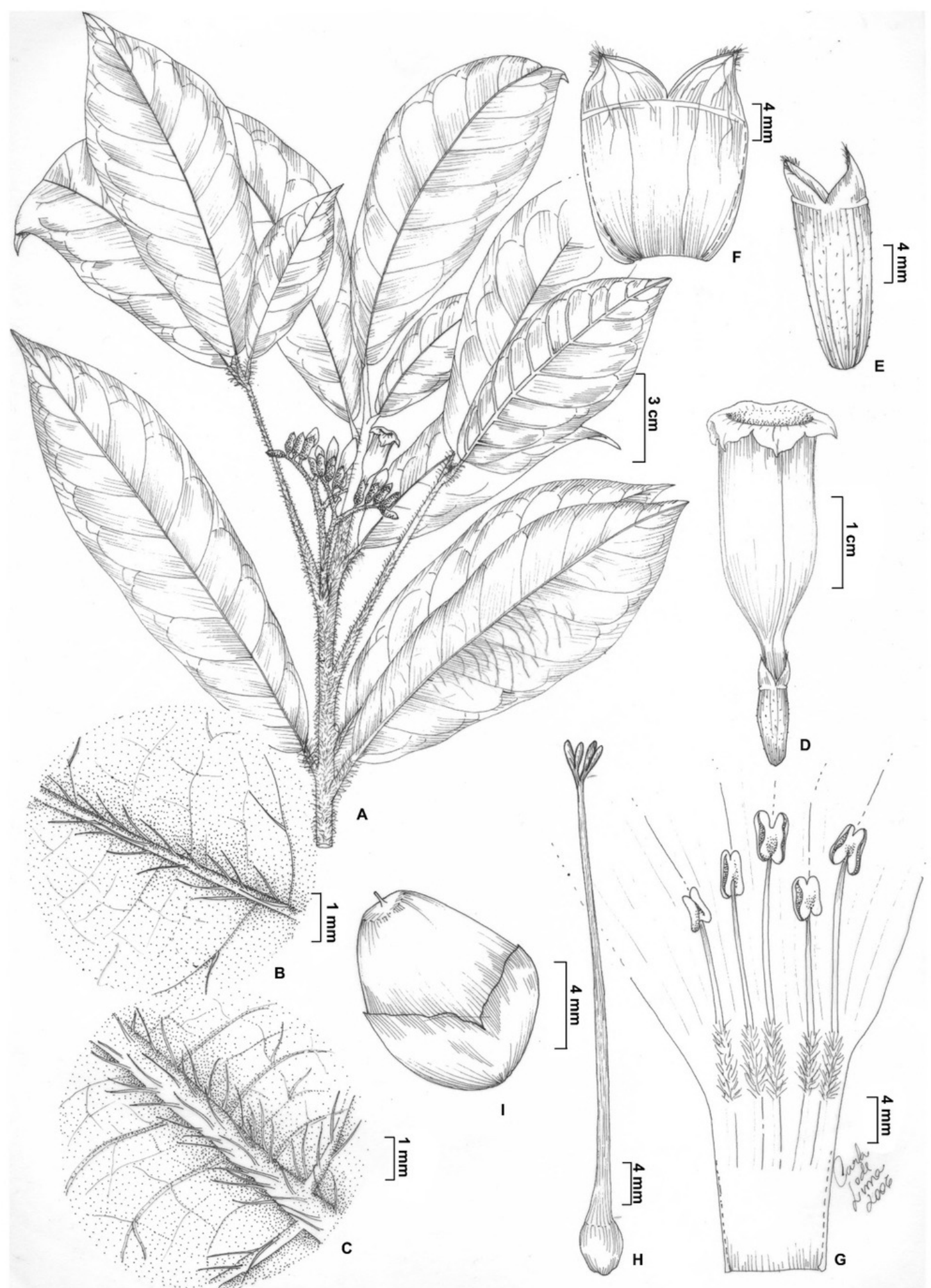

Figure 1. Cordia pilosa M. Stapf \& Taroda. - A. Flowering branch. - B. Adaxial surface of leaf midportion. - C. Abaxial surface of leaf midportion. - D. Flower. - E. Calyx. - F. Calyx opened. - G. Corolla opened to show the insertion of the stamens. - H. Gynoecium. - I. Fruit. A-H drawn from the type M. Stapf 228 (HUEFS); I drawn from M. Stapf 229 (HUEFS).

IUCN Red List category. The species should be considered Data Deficient (DD) according to IUCN Red List criteria (IUCN, 2001). Although it is known from several localities in the altered Atlantic coastal forest region, more information about the numbers of individuals and the extent of the habitat is needed.
Phenology. Flowering specimens were collected in October to March; fruits were collected in January to April.

Relationships. The new species is distinctive and easily distinguished from other species in Cordia sect. 
Superbiflorae by the pilose indument on the twigs, leaves, and inflorescences axes and by the reflexed corolla lobes. Cordia pilosa is closely related to $C$. superba Cham. and C. rufescens A. DC., sharing the large flowers (greater than $3 \mathrm{~cm}$ long). However, $C$. superba differs from $C$. pilosa by its indument that is scabrous with strigose hairs or often glabrescent, but never pilose, and by the spreading corolla lobes; $C$. rufescens can be distinguished from $C$. pilosa by its villous indument and smaller corolla $(3.0-3.5 \mathrm{~cm})$. Cordia pilosa appears to be distylous, as reported in other species of Cordia (Taroda \& Gibbs, 1986).

Paratypes. BRAZIL. Alagoas: Limoeiro de Anadia, 11 June 1981, A. D. Andrade-Lima, R. Pereira \& A. Du Bocage 75 (HUEFS); Barra de São Miguel, 25 Mar. 1986, R. P. LyraLemos \& G. L. Esteves 1190 (HUEFS, MAC); Penedo, 14 Nov. 1985, R. P. Lyra-Lemos \& A. T. L. Pinheiro 1103 (HUEFS, MAC); Coruripe, Colônia de Pindorama, 21 Oct. 1998, R. P. Lyra-Lemos \& M. N. Rodrigues 3979 (HUEFS, MAC); Piaçabuçu, Tapera, 22 Oct. 1987, I. S. Moreira, G. L. Esteves, R. P. Lyra-Lemos, R. S. Nascimento \& A. F. L. Pinheiro 59 (HUEFS, MAC); Campo Alegre, Faz. Matão, 25 Nov. 1997, M. N. Rodrigues, R. P. Lyra-Lemos \& J. Santinho 1174 (HUEFS, MAC). Bahia: Entre Rios, $11^{\circ} 53^{\prime} 08^{\prime \prime} \mathrm{S}$, $37^{\circ} 57^{\prime} 13^{\prime \prime} \mathrm{W}, 25$ Feb. 2005, J. G. Carvalho-Sobrino \& A. C. Assunção 347 (HUEFS); São Sebastião do Pessé, Faz. Panema $12^{\circ} 33^{\prime} \mathrm{S}, 38^{\circ} 23^{\prime} \mathrm{W}, 27$ Mar. 2001, G. Carvalho et al. 21 (ALCB); Conde, $30 \mathrm{~km}$ from Conde, 25 Mar. 1995, $F$. França \& E. Melo 1145 (HUEFS); Itanagra, Faz. Brejo Verde, 26 Oct. 1975, E. F. Gusmão 375 (ALCB); Conceição do Jacuipe, Rio Pojuca, $12^{\circ} 32^{\prime} \mathrm{S}, 39^{\circ} 05^{\prime} \mathrm{W}, 7$ Mar. 2003, $M$. V. Moraes 575 (HUEFS); Entre Rios, rd. to Imbé, $12^{\circ} 7^{\prime} 40^{\prime \prime} \mathrm{S}$, $37^{\circ} 59^{\prime} 14^{\prime \prime}$ W, 20 Jan. 2007, T. S. Nunes, N. K. R. Souza \& K. T. R. Souza 1767 (HUEFS); Mata de São João, praia Malhada, $12^{\circ} 30^{\prime} 37^{\prime \prime} \mathrm{S}, 38^{\circ} 00^{\prime} 36^{\prime \prime} \mathrm{W}, 18$ Nov. 2005, A. K. A. Santos, S. F. Conceição \& T. S. Nunes 468 (HUEFS); Entre Rios, rd. Conde-Esplanada, $11^{\circ} 45^{\prime} 17^{\prime \prime} \mathrm{S}, 37^{\circ} 45^{\prime} 45^{\prime \prime} \mathrm{W}, 23$ Jan. 2004, M. Stapf 201 (HUEFS, SJRP), M. Stapf 202
(HUEFS), M. Stapf 203 (HUEFS), M. Stapf 204 (HUEFS), 3 Feb. 2004, M. \& D. Stapf 229 (HUEFS, SJRP). Sergipe: Indiaroba, rd. to Pontal, ca. $1 \mathrm{~km}$ from hwy. SE 100, $11^{\circ} 28^{\prime} 57^{\prime \prime} \mathrm{S}, 37^{\circ} 27^{\prime} 37^{\prime \prime W}, 19$ Aug. 2003, K. R. B. Leite \& A. S. Conceição 337 (HUEFS).

Acknowledgments. We thank the Organization of American States (OAS) and the Secretaria Nacional de Ciencia y Tecnologia (SENACYT) of Panama for the Ph.D. fellowship for the first author and the Kew Latin America Research Fellowship Programme (KLARF) for providing support for visits to European herbaria. T. R. S. Silva was supported by the Conselho Nacional de Desenvolvimento Científico e Tecnológico (CNPq). We are grateful to Victoria C. Hollowell, Javier Estrada, and Juan Gaviria for their valuable suggestions to improve the manuscript. We thank the curators of the following herbaria for providing loans of specimens or access to collections: ALCB, BHCB, G, HUEFS, MAC, MBM, P, and SJRP. We also thank Cássio van den Berg for helping with the Latin diagnosis and Carla de Lima for the illustration.

\section{Literature Cited}

IUCN. 2001. IUCN Red List Categories and Criteria, Version 3.1. Prepared by the IUCN Species Survival Commission. IUCN, Gland, Switzerland, and Cambridge, United Kingdom.

Miller, J. S. 2001. New Boraginaceae from tropical America: 4. Three new species of Cordia from South America. Novon 11: 421-428.

$\&$ M. Gottschling. 2007. Generic classification in the Cordiaceae (Boraginales): Resurrection of the genus Varronia P. Br. Taxon 56(1): 163-169.

Taroda, N. \& P. E. Gibbs. 1986. Studies on the genus Cordia L. (Boraginaceae) in Brazil. 1. A new infrageneric classification and conspectus. Revista Brasil. Bot. 9: 31-42. 


\section{$2 \mathrm{BHL}$ Biodiversity Heritage Library}

De Stapf, María Natividad Sánchez, Ranga, Neusa Taroda, and Silva, Tânia Reginados Santos. 2010. "A New Species of Cordia (Cordiaceae, Boraginales) from Brazil." Novon a journal of botanical nomenclature from the Missouri Botanical Garden 20, 212-214.

View This Item Online: https://www.biodiversitylibrary.org/item/123332

Permalink: https://www.biodiversitylibrary.org/partpdf/122013

\section{Holding Institution}

Missouri Botanical Garden, Peter H. Raven Library

\section{Sponsored by}

Missouri Botanical Garden

\section{Copyright \& Reuse}

Copyright Status: Permission to digitize granted by rights holder Rights: https://www.biodiversitylibrary.org/permissions

This document was created from content at the Biodiversity Heritage Library, the world's largest open access digital library for biodiversity literature and archives. Visit BHL at https://www.biodiversitylibrary.org. 